\title{
Implementasi Pembiayaan Mudharabah Untuk Kegiatan Usaha Masyarakat Sebagai Upaya Pemulihan Ekonomi Nasional Akibat Pandemi Covid-19
}

\author{
Muhammad A1 Ikhwan Bintarto ${ }^{1 *}$, Yudi Setiawan ${ }^{2)}$ \\ ${ }^{1,2}$ Magister Ilmu Hukum, Universitas Muhammadiyah Yogyakarta \\ *Email korespondensi: m.al.psc.20@umy.mail.ac.id
}

Covid-19 pandemic in 2020 so dangerious, not only dangerios for a healty but dangerious too the country's economy. Much persons and companies in a country try how to recover country's economy one of them Islamic banking and Islamic Micro Finance. This research is intended to find out how the implementation of mudharabah financing on society businesses in an effort to recover the economy due to the Covid-19 pandemic in Islamic Banking. This research use a qualitative method. The data for this research collected from book, aritcle and the result of this research is to know how islamic micro financing product can recover a society business can improve and recover after facing covid-19 pandemic.

Keywords : Akad Mudharabah, economics recovery, covid-19

Saran sitasi: Bintarto, M. A. I., \& Setiawan, Y. (2021). Implementasi Pembiayaan Mudharabah Untuk Kegiatan Usaha Masyarakat Sebagai Upaya Pemulihan Ekonomi Nasional Akibat Pandemi Covid-19. Jurnal Ilmiah Ekonomi Islam, 7(02), 571-576. doi: http://dx.doi.org/10.29040/jiei.v7i2.2489

DOI: http://dx.doi.org/10.29040/jiei.v7i2.2489

\section{PENDAHULUAN}

Kegiatan pembiayaan yakni penyediaan dana atau barang oleh lembaga keuangan syariah kepada mitra nya selalma itu tidak bertentangan dengan syari'ah dan standar akutansi perbankan syariah, adapun tujuan dari pembiayaan oleh lembaga keuangan sendiri yaitu: 1 . Tujuan makro yaitu untuk meningkatkan perekonomian, menyediakan dana untuk perkembangan usaha, mendorong peningkatan produktivitas dalam hal pembukaan lapangan kerja, dan adanya pendistribusian pendapatan. 2. Adapun tujuan mikro nya adalah sebuah upaya guna meningkatkan laba, meminimalisasi resiko, mendayagunakan ekonomi.

Pembiayaan dalam bentuk mudharabah menggunakan skema bagi hasil antara sahibul maal (pemilik dana) dengan mudharib (pengelola dana) dan pembagiannya sesuai dengan keuntungan yang didapatkan dari usaha mudharib dengan akad yang telah disepakati antara kedua belah pihak.

Asal kata mudharabah yaitu dari bahasa arab dharb yang berarti memukul atau jalan, adapun penjelasan dari memukul dan jalan adalah proses seseorang menggerakkan anggota tubuhnya dalam menjalankan usahanya. Dan kata "mudharabah", "muqaradhah", "qiradh" memiliki atu arti dan makna yakni menyerahkan modal atau harta untuk diperniagakan oleh seseorang yang dipercayainya. Pendapat kebanyakan fuqaha tentang istilah mudharabah atau qiradh yaitu akad yang dilakukan dua belah pihak yang akan saling menanggung, satu pihak menyerahkan modal atau harta nya untuk diperdagangkan atau dikelola sedangkan hasil keuntungannya akan dibagikan seperi akad awal yang telah disepakati oleh mereka. Akad mudharabah sudah dikenal dan dipraktekkan dari zaman rasul, dan Rasulullah pernah melakukan akad mudharabah pada saat Khadijah mempercayai Nabi Muhammad SAW untuk menjual barang dagangannya ke luar negeri disini Khadijah sebagai (sahibul maal) dan Nabi Muhammad SAW sebagai mudharib atau yang melakukan usaha.(Mohammad Hirwan Bin Rusman, 2019) Dan akad mudharabah sendiri adalah akad pembiayaan yang digunakan oleh orang arab terdahulu dalam melaksanakan suatu perdagangan, seperti yang dijelaskan dalam hadist Ibnu Majah "Nabi Muhammad Shallahu'alaihi Wassalam menyampaikan kepada Suhayb ra, "tiga hal yang 
memiliki berkah (dari Allah SWT) yaitu penjualan yang ditangguhkan, mudharabah (bagi hasil keuntungan) dan mencampur gandum dengan gandum untuk keperluan rumah tangga (bukan untuk perdagangan)".(Edriyanti et al., 2020).

Pengertian akad mudharabah dalam undangundang No.21 tahun 2008 tentang perbankan syariah adalah perjanjian usaha antara sahibul maal dan mudharib, dengan pembagian keuntungan sesuai kesepakatan yang tertera dalam akad perjanjian, sedangkan untuk kerugian usaha akan ditanggung oleh bank syariah kecuali kedua belah pihak ada yang lalai dan mennyalahi akad yang telah diperjanjikan.(Edriyanti et al., 2020)

Sedangkan arti mudharabah dalam fatwa DSNMUI adalah "akad kerjasama suatu usaha antara dua pihak di mana pihak pertama (malik, shahib al-mal, LKS) menyediakan seluruh modal, sedang pihak kedua ('amil, mudharib, nasabah) bertindak selaku pengelola, dan keuntungan usaha dibagi di antara mereka sesuai kesepakatan yang dituangkan dalam kontrak"(DSN-MUI, 2000).

Adapun pengaturan pembiayaan dengan akad mudharabah telah dijelaskan dalam Undang-undang Nomor 21 tahun 2008 pasal 19 angka 1 huruf b, c, i tentang ketentuan bank umum syariah yangberbunyi: "Menghimpun dana dalam bentuk investasi berupa Depposito, Tabungan atau bentuk lainnya yang dipersamakan dengan itu dengan prinsip mudharabah atau akad lain yang tidak bertentangan dengan prinsip Syariah"

"Menyalurkan pembiayaan bagi hasil berdasarkan akad mudharabah, musyarakah, atau akad lain yang tidak bertentangan dengan prinsip Syariah"

"Membeli, menjual dan menjamin atas risiko sendiri surat berharga pihak ketiga yang diterbitkan atas dasar transaksi nyata berdasarkan prinsip Syariah, antara lain seperti akad Ijarah, musyarakah, mudharabah, murabahah, kafalah atau hawalah".("Undang. REPUBLIK Indones. NOMOR 21 TAHUN 2008 TENTANG Perbank. SYARIAH," 2008)

Dan kesimpulan dari definisi mudharabah adalah suatu akad kerjasama antara Shohibul maal (pemilik modal) dan mudharib (pengelola) dana untuk suatu usaha atau kegiatan yang produktif dan halal, yang kemudian keuntungan dari usaha tersebut dibagi sesuai nisbah tang tertera pada akad dan kerugian ditanggung oleh sahibul maal kecuali ada kesalahan atau lalai diantara keduanya(Rani Handani, 2018).

Pembiayaan untuk UMKM dapat meningkatkan keuntungan dan tambahan modal untuk pengusaha apabila ia dapat mengelola dana dan usahanya dengan baik, Pembiayaan dengan akad mudharabah adalah dimana perbankan syariah memberikan modal $100 \%$ untuk nasabah atau pengelola usaha dengan bentuk Qardh, pembiayaan dengan akad mudharabah di perbankan syariah ini dapat memberikan keuntungan yang besar untuk pihak bank akan tetapi pembiayaan ini juga memiliki resiko yang tinggi apabila salah satu pihak lalai atau kurang baik dalam pengelolaannya. Qardh sendiri merupakan pinjaman lunak yang diberikan oleh pihak bank untuk nasabahnya tanpa imbalan.(Afkar, 2017).

Perbankan syariah dengan pembiayaan mudharabahnya dapat menjadi sebuah lembaga keuangan yang berfungsi sebagai media perputarran dana moneter antara surplus kapital beserta yang minus kapital akan tetapi memiliki skill atau ketrampilan, dikarenakan pembiayaan dengan model mudharabah mempunyai fasilitas dengan bentuk profit sharing dan partnership dengan arti lain pembiayaan dengan akad mudharabah mempunyai peran yang dapat menggerakkan dinamika perekonomian mikro dalam masyarakat dan dari pelajuan ekonomi tersebut dapat memberikan dampak yang baik dan positif untuk masyarakat juga diantaranya mengurangi penggangguran, menyerap tenaga kerja, menambah permodalan pelaku usaha dan disinilah peran akad dalam bank syariah yang berprinsip islami dpat memberikan sumbangsih kepada pelajuan ekonomi Nasiona, seperti yang dijelaskan dalam visi didirikannya bank syariah yaitu "Terwujudnya sistem perbankan syariah yang kompetitif, efisien dan memenuhi prinsip kehatihatian serta mampu mendukung sektor riil secara nyata melelui kegiatan pembiayaan berbasis bagi hasil dan transaksi riil dalam kerangak keadilan, tolong menolong dan menuju kebaikan guna mencapai kemaslahatan masyarakat".(Ibrahim, 2014)

Ketentuan bagi hasil dengan akad mudharabakh yang di aplikasikan oleh perbankan syariah menggunakan dua pendekatan yaitu : a). hasil investasi tersebut dibagi antara pengelola dana dengan pemilik dana dengan nisbah yang telah disepakati oleh kedua belah pihak, dengan porsi masing masing. $b$ ). hasil investasi tersebut dibagi antarapemilik dana sesuai dengan porsi modal masing-masing selanjutnya 
bagian hasil investasi setelah dikurangi untuk pengelola dana sesuai dengan nisbah yang telah ditentukan.(Maruta, 2016)

Indonesia telah mengalami beberapa kali krisis yaitu pada tahun 1997-1998 yang memperlihatkan kegagalan pasar dan krisis juga terjadi pada tahun 2007-2008 yaitu krisis bahan bakar minyak hingga krisis pangan yang terjadi di banyak belahan dunia kala itu sehingga sangat berdampak bagi kestabilan perekonomian nasional, dan kebijakan pemerintah pada tahun 1997-1998 adalah memberikan stimulus pendanaan untuk pelaku ekonomi (terkhusus bank yang bangrut) yang tak lalin untuk mendorng dan memberikan efek positif bagi perekonomian Indonesia.(Burhanuddin \& Abdi, 2020).

Menurut Singgih (2007) mengemukakan bahwa UMKM adalah salah satu basis perekonomian masyarakat dan sebagai tempat naungan para pelaku ekonomi, UMKM bisa dikatakan sebagai dinamisator perekonomian Nasional dalam pemulihan ekonomi setelah terjadinya krisis ekonomi dikarenakan UMKM bergerak lebih awal, cepat dan dengan keadaan yang ada. Dan inilah yang terjadi pada tahun 1997, pasca krisis eknomi 1997 UMKM mampu menyerap banyak tenaga kerja, dengan itu masyarakat mendapatkan penghasilan. Pada dasarnya UMKM adalah pemain lokal yang dominan dalam perluasan perekonomian di daerah(Nasrun et al., 2020).

Piter Abdullah Redjalem (Direktur Riset Core of Reform on Economics) menyebutkan bahwa kondisi resesi sejak pandemi covid-19 menumbuhkan kebiasaan baru di seluruh dunia dan yang membedakan adalah kedalaman serta kecepatan suatu negara untuk recovery, dengan banyaknya UMKM di penjuru negeri, bisa menjadi pendorong pemulihan perekonomian di Indonesia. Terhitung menurut BPS (Badan Pusat Statistik) jumlah UMKM sekitar 64 juta dan menurut Kemenkop UKM (Kementerian Koperasi dan Usaha Kecil Menengah) terdapat sekitar 8 juta UMKM yang telah memanfaatkan media online sebagai pasar dari produknya dari 13 persen jumlah usaha di Indonesia.(Soleha, 2020)

Penelitian ini akan membahas tentang bagaimana peran pembiayaan dengan akad mudharabah menjadi salah satu solusi untuk pemulihan ekonomi akibat covid-19 dan pasca covid-19, karena hal ini selaras dengan program PEN (pemulihan ekonomi nasional) yang dikeluarkan oleh pemerintah dalam PP No. 23 tahun 2020 tentang pelaksanaan program pemulihan ekonomi nasional dalam rangka mendukung kebijakan keuangan negara untuk penanganan pandemi covid-19.

\section{METODE PENELITIAN}

Jenis penelitian yang digunakan oleh penulis adalah penelitian kualitatif, dalam penelitian ini akan dilihat bagaimana implementasi pembiayaan mudharabah oleh lembaga keuangan syariah untuk permodalan kegiatan usaha masyarakat yang diharapkan dapat menjadi sebuah upaya pemulihan ekonomi nasional meskipun dalam kondisi pandemi Covid-19. penulis menggunakan metode studi literatur dimana sumber data diambil dan dikumpulkan dari buku, jurnal,penelitian terdahulu atau dari website yang kemudian dibaca dan diolah menjadi bahan penelitian.

\section{HASIL DAN PEMBAHASAN}

\subsection{Definisi, Rukun, dan Implementasi mudharabah di Perbankan Syariah \\ Definisi Mudharabah}

Dalam fikih muamalat, definisi mudharabah diungkapkan oleh empat madzhab berarti: menurut madzhab Hanafi, mudharabah yakni suatu akad dalam pelaksanaan kongsi untuk memperoleh keuntungan dari modal yang diberikan oleh suatu pihak dan kerja atau usaha dari pihak lainnya, menurut madzhab Maliki, mudharabah adalah penyerahan dana diawal oleh pemodal dalam jumlah yang ditrntukan kepada suatu pihak yang menjalankan usahanya dengan dana tersebut dengan disertai dengan imbalan dari keuntungan usaha yang dijalankannya, menurut madzhab Hambali mudharabah ialah pemberian barang atau sejenisnya dalam jumlah yang terlah jelas untuk orang yang mengusahakannya dengan ia mendapat bagian dari keuntungannya, sedangkan mudharabah menurut madzhab Syafi'i ialah penyerahan uang kepada pengusaha dalam usaha dagang dan keuntungannya milik bersama antara keduanya.(OJK, 2017)

Jadi mudharabah adalah akad kerjasama antasa sahibul maal dan mudharib dalam suatu proyek atau kegiatan usaha tertentu yang keuntungannya dibagi dua sesuai kesepakatan saaat pertama akad.

\section{Rukun Mudharabah}

Adapun rukun dari pembiayaan mudharabah sendiri antara lain; pemilik dana (sahibul maal) dan pengelola (mudharib), modal, usaha pengelola modal, keuntungan, ijab dan qabul (shigah aqad) 
Jurnal Ilmiah Ekonomi Islam, 7(02), 2021, 574

\section{Implementasi pelaksanaan akad mudharabah untuk usaha kegiatan masyarakat}

Implementasi akad mudharabah di perbankan syariah kontemporer ini banyak megalami transformasi apabila dibandingkan dengan konsep mudharabah klasik, konsep akad mudharabah kini dapat digabungkan dengan akad lain seperti akad murabahah dan musyarakah, pertimbangan ini menyesuaikan dengan kebutuhan masyarakat yang semakin kompleks dan menyesuaikan dengan keadaan masyarakat kini. Konsep mudharabah klasik tidak ada mekanisme angsuran dalam pembayaran modal pokok yang telah dikelola oleh mudharib, adapun pembayaran modal tersebut dilakukan hanya satu kali pada akhir kontrak. Konsep ini juga untuk pembayaran bagi hasil akad mudharabah, yang pembayarannya dilakukan pada akhir kontrak.(OJK, 2017)

Persyaratan untuk calon nasabah mudharabah antara lain:

1. Memenuhi standar kriteria sebagai nasabah

2. Lama usaha calon nasabah

3. Calon nasabah telah menjalankan usahanya minimal 2 tahun untuk nasabah walk in client

4. Calon nasabah menjalankan usahanya minimum 1 tahun dan memiliki manajemen usaha yang baik dan mendapat rekomendasi dari nasabah eksisting

5. Mempunyai kolektabilitas minimum lancar (kolektabilitas 1) 6 bulan berturut-turut ketika ia mempunyai pembiayaan lainnya di lembaga pembiayaan yang berbeda

6. Calon nasabah harus memiliki rekening giro di bank yang bersangkutan

7. Usaha calon nasabah harus memenuhi prinsipprinsip syariah dan tidak menyalahi syariah

8. Melengkapi dan menyerahkan lampiran dokumen kepada bank guna menganalisa pembiayaan

Prosedur pembiayaan mudharabah di Perbankan syariah:

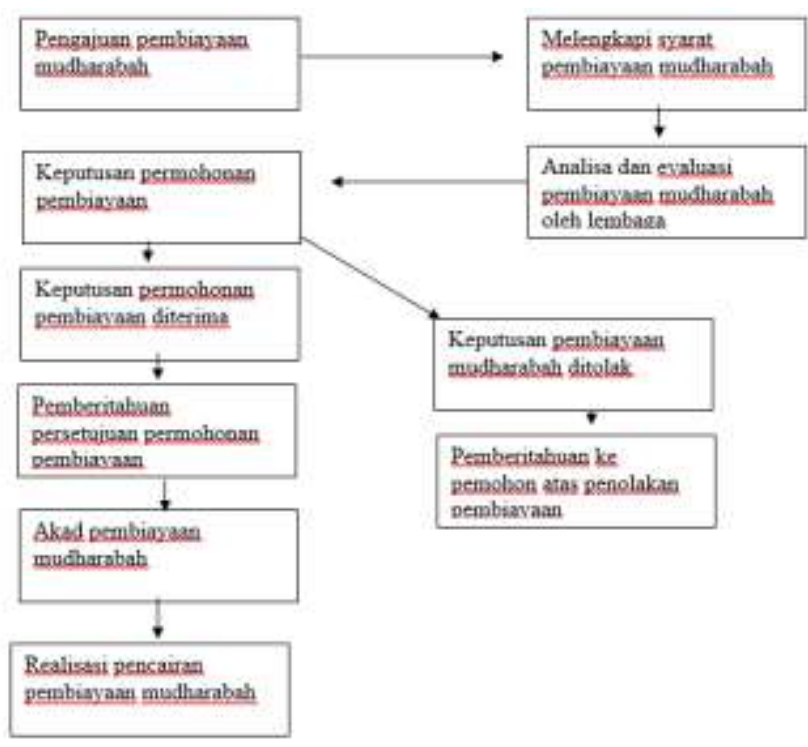

Gambar 1

Sumber: BNI Syariah

3.2. Implementasi pembiayaan dengan akad mudharabah terhadap program pemulihan ekonomi Nasional.

Selama pandemi covid-19, dunia usaha tidak terkecuali usaha masyarakat mengalami banyak gangguan yang cukup signifikan baik dalam permodalan, operasioanl, produksi maupun distribusi, Program Pemulihan Ekonomi Nasional (PEN) dibuat oleh Pemerintah adalah suatu bentuk respon kebijakan dalam upaya menjaga dan menghindari aktivitas usaha dari pemburukan lebih lanjut dikarenakan pandemi covid-19 yang kemungkinan dapat membahayakan Perekonomian Nasional dan stabilitas perekonomian, mengurangi banyaknya pemutusan hubungan kerja dengan cara memberikan subsidi untuk pelaku usaha mikro, kecil, menengah guna mempercepat pemulihan ekonomi Nasional.

Pasal 10 ayat 1 berbunyai dalam rangka pelaksanaan program PEN, Pemerintah dapat melakuakn Penempatan dana yang ditujukan untuk memberikan dukungan likuiditas kepada perbankan yang melakukan restukurisasi kredit/pembiayaan atau memberikan kredit dan pembiayaan modal kerja.(2O2O, 2019)

Pembiayaan di bank syariah maupun di BPRS dapat menjadi salah satu solusi dalam pemulihan perekonomian Nasional dikarenakan dengan pembiayaan tersebut bisa menjadi tambahan modal untuk UMKM yang terhambat dalam permodalan dikarenakan pandemi Covid-19. Diantaranya pembiayaan dengan akad mudharabah. 
Berikut diantaranya pembiayaan mudharabah dapat memberikan solusi dalam pemulihan ekonmi Nasional dikarenakan:

1. Pembiayaan mudharabah sebagai dapat mendorong peningkatan ekosistem berwirausaha, dikarenakan di dalam mudharabah terdapar nilai kekeluargaan, gotong royong dan dinilai tepat untuk mendorong perkembangan perekonomian masyarakat.

2. Pembiayaan mudharabah dapat memberdayakan usaha mikro menengah secara produktif di Indonesia.

3. Pembiayaan mudharabah mampu memberikan pendistribusian penghasilan yang adil serta stabilitas ekonomi yang bagus.

Adapun tujuan lain dari pembiayaan yang dilakukan oleh bank syariah adalah meningkatan ekonomi umat, menyediakan dana guna peningkatan usaha masyarakat, meningkatkan produktivitas dan dapat membuka lapangan pekerjaan baru dan terjadinya distribusi pendapatan.(Antonio, 2016)

\section{KESIMPULAN}

Hasil penelitian diatas penulis menyimpulkan bahwa pembiayaan di perbankan syariah dapat menunjang pemulihan ekonomi Nasional dan bisa menjadi salah satu solusi untuk pelaku usaha UMKM untuk keluar dari permasalahan ekonomi akibat terdampak pandemi covid-19. Salah satu pembiayaan yang dapat mendorong pertumbuhan ekonomi pelaku usala UMKM adalah mudharabah dikarenakan pembiayaan dengan akad mudharabah dapat meningkatkan ekosistem berwirausaha, pembiayaan dengan akad mudharabahh dapat memberdayakan UMKM dengan produktif di Indonesia, pembiayaan dengan akad mudharabah dapat menmberikan pendistribusian penghasilan yang adil dan stabilitas ekonomi yang bagus serta pembiayaan dengan akad mudharabah dapat menstabilkan permodalan pelaku usala UMKM.

Penulis menyarankan agar perbankan syariah atau BPRS dapat mengoptimalkan akad pembiayaan untuk usaha masyarakat baik akad mudharabah atau akad lainnya sehingga dapat mendukung program pemulihan ekonomi Nasional yang iupayak oleh Pemerintah.

\section{UCAPAN TERIMA KASIH}

Penulis mengucapkan terimakasih sebesarbesarnya untuk segala piihak yang berkontribusi pada penyelesaian naskah penelitian ini sehingga dapat diselesaikan dengan baik dan penulis memohon maaf apabila masih banyak kekurangan dalam penelitiiain yang penulis lakukan.

\section{REFERENSI}

2O2O, P. P. R. I. N. 23 T. (2019). Peraturan Pemerintah Republik Indonesia Nomor 23 Tahun 2020 Tentang Pelaksanaan Program Pemulihan Ekonomi Nasional Dalam Rangka Mendukung Kebijakan Keuangan Negara Untuk Penanganan Pandemi Corona Yirus Dt.Sease 2019 (COVID19) Dan/Atau Menghadapi Ancaman (Issue 037267).

Afkar, T. (2017). Influence Analysis of Mudharabah Financing and Qardh Financing to The Profitability of Islamic Banking in Indonesia. AJIE - Asian Journal of Innovation and Entrepreneurship, 02(03), 340-351.

Antonio, M. S. (2016). Pengaruh Pembiayaan Mudharabah Terhadap Peningkatkan Kesejahteraan Pelaku Umkm (Studi Kasus BMT Maslahah Capang Pandaan). Jurnal Malia, 7(2), 287-310.

Burhanuddin, C. I., \& Abdi, M. N. (2020). Ancaman Krisis Ekonomi Global Dari Dampak Penyebaran Virus Corona (COVID-19). Krisis, Ancaman Global, Ekonomi Dampak, Dari, 17, 710-718.

DSN-MUI. (2000). Fatwa Dewan Syari'ah Nasional No. 07/DSN-MUI/IV/2000. Himpunan Fatwa DSN MUI, 5.

Edriyanti, R., Chairina, \& Khairunnisa, A. (2020). Analisis Pengaruh Pembiayaan Mudharabah, Musyarakah, Murabahah Dan Npf Terhadap Roa (Studi Kasus Bprs Di Indonesia. Jurnal Nisbah, 6(2), 63-74.

Ibrahim, K. (2014). Mudharabah Principle of Banking Products. Kajian Hukum Dan Keadilan IUS, 4253.

Maruta, H. (2016). Akad Mudharabah,Musyarakah,Dan Murabahah Serta Aplikasinya Dalam Masyarakat. IQTISHADUNA: Jurnal Ilmiah Ekonomi Kita, $5(9), 88$.

Mohammad Hirwan Bin Rusman. (2019). Analisis Implementasi dan Hambatan Pembiayaan Sistem Mudharabah Pada Modal Kerja di PT. Bank Muamalat Indonesia, JAKARTA. Journal of Chemical Information and Modeling, 53(9), 1689-1699. 
Jurnal Ilmiah Ekonomi Islam, 7(02), 2021, 576

Nasrun, M. A., Ekonomi, F., \& Tanjungpura, U. (2020). Kekuatan Dasar Pemulihan Ekonomi Pasca Covid-19 di Kabupaten Kapuas Hulu. Prosiding Seminar Akademik Tahunan Ilmu Ekonomi Dan Studi Pembangunan, 32-40.

OJK, T. (2017). Standar Produk Mudharabah. 1-292.

Rani Handani, I. J. H. (2018). Pembiayaan Mudharabah Sebagai Instrumen Pembiayaan Islam Di Indonesia: Analisis Studi Literatur Rani. Journal of Chemical Information and Modeling, 53(9), 1689-1699.
Soleha, A. R. (2020). Kondisi UMKM Masa Pandemi Covid-19 Pada Pertumbuhan Ekonomi Krisis Serta Program Pemulihan Ekonomi Nasional. Jurnal Ekombis, 6(2), 165-178.

Undang-Undang Republik Indonesia Nomor 21 tahun 2008 tentang Perbankan Syariah. (2008). Undang-undang Republik Indonesia Nomor 21 Tahun 2008 tentang Perbankan Syariah. 